\title{
FAKTOR - FAKTOR YANG BERHUBUNGAN DENGAN KEPATUHAN PENGOBATAN PADA PASIEN DIABETES MELITUS DI WILAYAH KERJA PUSKESMAS DAIK
}

\author{
Fatmawati $^{1}$,Rizki Sari Utami ${ }^{2}$, Siska Natalia ${ }^{3}$ \\ ${ }^{1}$ Program Studi Ilmu Keperawatan \\ STIKes Awal Bros Batam Jl.Abultayama Kelurahan Belian Kecamatan Kota Batam \\ Email : fatmawati.wati2015@gmail.com
}

\begin{abstract}
ABSTRAK
Keberhasilan suatu pengobatan, dipengaruhi oleh kepatuhan penderita Diabetes Melitus untuk menjaga kesehatannya. Dengan kepatuhan yang baik, pengobatan dapat terlaksana secara optimal dan kualitas kesehatan bisa tetap dirasakan. Tujuan dari penelitian ini adalah Untuk mengetahui gambaran pengetahuan, dukungan keluarga, sarana prasarana dan peran petugas kesehatan terhadap kepatuhan pengobatan penderita Diabetes mellitus serta menganalisa faktor-faktor yang berhubungan dengan kepatuhan pasien diabetes militus dalam menjalani pengobatan di wilayah kerja Puskesmas Daik. Penelitian ini menggunakan pendekatan cross sectional dengan cara observasional, pemilihan sampel dengan tekhik random sampling. jumlah sampel 60 responden. Hasil penelitian diuji dianalisa dengan uji Chi square dengan perolehan hasil uji Chi-square terdapat hubungan antara faktor Pengetahuan dengan kepatuhan pengobatan diabetes mellitus (nilai $p=0,000$ ), terdapat hubungan antara dukungan keluarga dengan kepatuhan pengobatan diabetes mellitus (nilai $p=0,000$ ), terdapat hubungan antara sarana dan prasarana dengan kepatuhan pengobatan diabetes mellitus (nilai $p=0,000$ ), serta terdapat hubungan antara peran petugas dengan kepatuhan pengobatan pasien diabetes mellitus (nilai $p=0,000$ ). Saran peneliti kepada Petugas kesehatan agar dapat memberika edukasi terhadap pasien diabetes guna menambah pengetahuan pasien tentang pengobatan diabetes melitus sehingga diharapkan dapat meningkatkan kepatuhan pasien terhadap pengobatan dan kepada perawat agar dapat menyadari pentingnya peran dan dukungan petugas kesehatan untuk membantu meningkatkan kepatuhan pengobatan pasien diabetes.
\end{abstract}

Kata kunci: Pengetahuan, dukungan keluarga, Kepatuhan pengobatan

\begin{abstract}
The success of a treatment is strongly influenced by the compliance of people with Diabetes Mellitus to maintain their health. The purpose of this study was to determine the description of knowledge, family support, infrastructure and the role of health workers on treatment adherence to diabetes mellitus sufferers and to analyze factors related to diabetes mellitus patient compliance in undergoing treatment in the working area of Daik Health Center. This study used a cross sectional approach with an observational way, the sample selection was done by using random sampling technique. The number of samples used was 60 respondents. The results of the study were analyzed using the Chi square test, with the results obtained based on the Chi-square test, there was a relationship between knowledge factors and diabetes mellitus treatment adherence $(p$ value $=0,000)$, there was a relationship between family support and diabetes mellitus treatment adherence $(p=0,000)$, there is a relationship between facilities and infrastructure with adherence to diabetes mellitus treatment ( $p$ value $=0,000$ ), and there is a relationship between the role of officers and adherence to treatment of diabetes mellitus patients ( $p$ value $=0,000)$. Researchers suggest to health workers in order to provide education to diabetes patients in order to increase patient knowledge about diabetes mellitus treatment so that it is expected to increase patient adherence to treatment and to nurses in order to realize the importance of the role and support of health workers to help improve adherence to treatment of diabetes patients.
\end{abstract}

Key words: Knowledge,family support, , medication compliance 


\section{PENDAHULUAN}

Diabetes Melitus adalah salah satu penyakit gangguan metabolik menahun yang ditandai oleh kadar gulukosa darah yang melebihi nilai normal..Diabetes Melitus dikenal sebagai silent killer karena sering tidak diketahui penyandangnya dan saat diketahui sudah terjadi komplikasi (Kemnenkes, 2013). WHO memprediksikan Indonesia,akan ada kenaikan prevalensi Diabetes mellitus dari 8,4 juta diabetesi pada tahun 2000 menjadi 14 juta diabetes pada tahun 2006 dan akan meningkat tiga kali lipat dalam kurun waktu 30 tahun menjadi sekitar 21,3 juta pada tahun 2030. Hal ini menandakan Indonesia menduduki negara peringkat ke-4 dunia setelah Amerika Serikat, China dan India dengan masalah Diabetes (WHO.2015). Prevalensi Diabetes Melitus menurut Riskesdas (Riset Kesehatan Dasar) di Indonesia pada Tahun 2018 menunjukkan bahwa prevalensi Diabetes Militus nasional adalah sebesar $(2,0 \%)$ dengan prevalensi tertinggi ditemukan di Provinsi DKI $(3,4 \%)$, dan Provinsi NTT mempunyai prevalensi Diabetes melitus terendah yaitu $(0,9 \%)$ yang dilakuan pada penduduk usia $\geq 15$ tahun. Berdasarkan jenis kelamin penderita diabetes melitus lebih banyak diderita oleh perempuan yaitu $12,7 \%$ sedangkan laki- laki sebanyak 9,0 $\%$ dan lebih banyak diderita oleh masyarakat perdesaan yaitu $11,2 \%$ dibandingkan perkotaan yaitu $10,6 \%$. Sedangkan untuk didaerah kepulauan Riau penyakit Diabates mellitus menduduki 10 penyakit terbanyak pada tahun 2018 sehingga prevalensi Diabetes Melitus yaitu $(1,8 \%)$.

Keberhasilan suatu pengobatan, sangat dipengaruhi oleh kepatuhan penderita Diabetes Melitus untuk menjaga kesehatannya. Dengan kepatuhan yang baik, pengobatan dapat terlaksana secara optimal dan kualitas kesehatan bisa tetap dirasakan. Dampak dari ketidak pahaman tentang penykit Diabetes Melitus, banyak pasien Diabetes Melitus yang tidak patuh serta mengalami komplikasi dan mengakibatkan penyakitnya bertambah parah baik akut maupun kronis seperti komplikasi pada kardiovaskuler/pembuluh darah otak dapat mengakibatkan stroke, pada pembuluh darah mata (retinopati) dapat mengakibatkan kebutaan, penyakit ginjal (nefropati), penyakit saraf (neuropati ) dan periodontitis (radang jaringan di sekitar gigi ), kaki diabetic (ulserasi kaki dan amputasi ) dan disfungsi otak bahkan yang lebih parah komplikasi akut dapat menyebabkan diabetic ketoasidosis (DKA), koma diabetes hiperglikemi, kejang atau kehilangan kesadaran dan infeksi (Piemonte,2019).

Adapun faktor lain yang sudah melakukan penelitian yaitu penelitian Mareeya (2017) diketahui bahwa terdapat faktor yang berhubungan dengan tingkat kepatuhan penggunaan obat pada pasien Diabetes Melitus, hal ini dikarenakan pasien yang banyak lupa minum obat dan ketika pasien meninggalkan rumah pasien juga lupa membawa obat.

Penelitian ini bertujuan untuk mengetahui faktor-faktor yang berhubungan dengan kepatuhan pasien diabetes militus dalam menjalani pengobatan di wilayah kerja Puskesmas Daik. Tahun 2020.

\section{METODE PENELITIAN}

Jenis penelitian ini adalah menggunakan desain kuntitatif dengan pendekatan cross sectional, dengan cara pendekatan observasi atau pengumpulan data sekaligus pada suatu saat (point time approach) (Gahayu, 2014). Teknik pengambilan sampel pada penelitian ini menggunakan metode random sampling. Alat pengumpulan data dengan kuesioner yang dibagikan kepada responden. Hasil penelitian dianalisa dengan uji chi square.

\section{HASIL DAN PEMBAHASAN}

1. Analisa univariat

a. Distribusi frekuensi berdasarkan

karakteristik responden 
Tabel 4.1

Distribusi Frekuensi Karakteristik Usia, Jenis Kelamin, Status perkawinan,Pendidikan, dan Tempat Tinggal Responden Pasien Diabetes Melitus Di Wilayah Kerja Puskesmas

Daik Tahun 2020

\begin{tabular}{|c|c|c|c|}
\hline No & Karakteristik & $\begin{array}{l}\text { Frekuensi } \\
\text { (f) }\end{array}$ & $\begin{array}{c}\text { Persentase } \\
(\%)\end{array}$ \\
\hline \multirow[t]{5}{*}{1} & Umur & & \\
\hline & a. $35-45$ tahun & 5 & 8,3 \\
\hline & b. $46-55$ tahun & 24 & 40,0 \\
\hline & c. 56-65 tahun & 18 & 30,0 \\
\hline & d. 66-75 tahun & 13 & 21,7 \\
\hline \multirow[t]{3}{*}{2} & Jenis kelamin & & \\
\hline & a. Laki laki & 22 & 36,7 \\
\hline & b. Perempuan & 38 & 63,3 \\
\hline \multirow[t]{7}{*}{3} & Pekerjaan & & \\
\hline & a. Tidak bekerja & 10 & 16,7 \\
\hline & b. Buruh & 20 & 33,3 \\
\hline & c. Wiraswasta & 14 & 23,3 \\
\hline & d. PNS & 5 & 8,4 \\
\hline & e. Swasta & 8 & 13,3 \\
\hline & f. lainnya & 3 & 5,0 \\
\hline \multirow[t]{5}{*}{4} & Pendidikan & & \\
\hline & a. SD & 12 & 20,0 \\
\hline & b. SMP & 26 & 43,3 \\
\hline & c. SMU/ SMK & 17 & 28,3 \\
\hline & d. Perguruan Tinggi & 5 & 8,4 \\
\hline \multirow[t]{5}{*}{5} & Asuransi pengobatan & & \\
\hline & a. BPJS Pemerintah & 38 & 63,3 \\
\hline & b. BPJS Mandiri & 12 & 20,0 \\
\hline & c. Umum/Mandiri & 6 & 10,0 \\
\hline & d. Asuransi lainnya & 4 & 6,7 \\
\hline \multirow[t]{3}{*}{6} & Lama menderita DM & & \\
\hline & a. $<5$ tahun & 12 & 20,0 \\
\hline & b. $>5$ tahun & 48 & 80,0 \\
\hline \multirow[t]{3}{*}{7} & Status pernikahan & & \\
\hline & a. BelumMenikah & 8 & 13,3 \\
\hline & b. Menikah & 52 & 86,7 \\
\hline \multirow[t]{6}{*}{8} & Tempat tinggal & & \\
\hline & a. Tinggal sendiri & 4 & 6,7 \\
\hline & b. bersama orang tua/ saudara & 5 & 8,3 \\
\hline & c. bersama anak & 18 & 30,0 \\
\hline & d. Bersama suami/isteri & 12 & 20,0 \\
\hline & e. Bersama Suami/istri dan anak & 21 & 35,0 \\
\hline
\end{tabular}

Berdasarkan tabel 4.1 dapat diketahui bahwa persentase responden tertinggi pada distribusi usia 46-55 tahun yaitu sebanyak 24 orang $(40,0 \%)$, persentase tertinggi pada distribusi jenis kelamin yaitu perempuan sebanyak 38 orang $(63,3 \%)$, persentase 
tertinggi pada distribusi status perkawinan yaitu status menikah sebanyak 52 orang $(86,7 \%)$, persentase tertinggi pada distribusi pendidikan terbanyak pada tingkat SMP yaitu sebanyak 26 orang $(43,3 \%)$, dan persentase tertinggi pada distribusi tempat tinggal yaitu tinggal bersama suami/isteri dan anak sebanyak 21 orang $(35 \%)$.

b. Distribusi frekwensi berdasarkan pengetahuan responden

Tabel 4.2

Distribusi frekwensi pengetahuan responden Pasien Diabetes Melitus Di Wilayah Kerja Puskesmas Daik Tahun 2020

\begin{tabular}{llc}
\hline Pengetahuan & f & $\%$ \\
\hline Baik & 30 & 50,0 \\
Cukup & 18 & 30,0 \\
Kurang & 12 & 20,0 \\
\hline Total & $\mathbf{6 0}$ & $\mathbf{1 0 0}$
\end{tabular}

Dari tabel 4.2 didapatkan hasil bahwa tertinggi dengan pengetahuan baik yaitu distribusi frekwensi pengetahuan responden sebanyak 30 orang $(50 \%)$.

c. Distribusi frekwensi berdasarkan dukungan keluarga

Tabel 4.3

Distribusi frekwensi dukungan keluarga Pasien Diabetes Melitus Di Wilayah Kerja Puskesmas Daik Tahun 2020

\begin{tabular}{clc}
\hline Dukungan keluarga & f & $\%$ \\
\hline Baik & 27 & 45,0 \\
Cukup & 20 & 33,3 \\
Kurang & 13 & 21,7 \\
\hline Total & 60 & 100
\end{tabular}

Dari tabel 4.3 didapatkan hasil bahwa tertinggi dengan dukungan keluarga baik distribusi frekwensi dukungan keluarga yaitu sebanyak 27 orang $(45,0 \%)$.

d. Distribusi frekwensi berdasarkan sarana prasarana

Tabel 4.4

Distribusi frekwensi sarana prasarana Fasilitas Kesehatan Di Wilayah Kerja Puskesmas Daik Tahun 2020

\begin{tabular}{ccc}
\hline Sarana prasarana & f & $\%$ \\
\hline Baik & 45 & 75,0 \\
Kurang & 15 & 25,0 \\
\hline Total & 60 & 100
\end{tabular}

Dari tabel 4.4 didapatkan hasil bahwa dengan sarana prasarana baik yaitu sebanyak distribusi frekwensi sarana prasarana tertinggi 45 orang $(75,0 \%)$.

e. Distribusi frekwensi berdasarkan peran petugas kesehatan

Tabel 4.5

Distribusi frekwensi peran petugas kesehatandi Wilayah Kerja Puskesmas Daik Tahun

\begin{tabular}{clc} 
& 2020 & $\%$ \\
\hline peran petugas kesehatan & $\mathrm{f}$ & \\
\hline Baik & & 75,0 \\
Kurang & 45 & 25,0 \\
\hline Total & 15 & $\mathbf{1 0 0}$ \\
\hline
\end{tabular}


Dari tabel 4.5 didapatkan hasil bahwa distribusi frekwensi peran petugas kesehatan tertinggi dengan peran petugas kesehatan baik yaitu sebanyak 45 orang $(75,0 \%)$.

f. Distribusi frekwensi berdasarkan kepatuhan pengobatan

Tabel 4.6

Distribusi frekwensi kepatuhan pengobatanPasien Diabetes Melitus Di Wilayah Kerja Puskesmas Daik Tahun 2020

\begin{tabular}{clc}
\hline Kepatuhan pengobatan & $\mathrm{f}$ & $\%$ \\
\hline patuh & 36 & 60,0 \\
tidak patuh & 24 & 40,0 \\
\hline
\end{tabular}

\begin{tabular}{ccc}
\hline Total & 24 & 40,0 \\
\hline 4.6 didapatkan & $\mathbf{6 0}$ & $\mathbf{1 0 0}$ \\
\hline
\end{tabular}

Dari tabel 4.6 didapatkan hasil bahwa tertinggi yaitu patuh sebanyak 36 orang distribusi frekwensi kepatuhan pengobatan (60,0\%).

2. Analisa Bivariat

a. Analisa hubungan pengetahuan responden dengan kepatuhan pengobatan

Tabel 4.7

Hubungan Pengetahuan Responden Dengan Kepatuhan Pengobatan Pasien Diabetes Melitus Di Wilayah Kerja Puskesmas Daik

Tahun 2020

\begin{tabular}{|c|c|c|c|c|c|c|c|}
\hline \multirow{3}{*}{ Pengetahuan } & \multicolumn{4}{|c|}{ Kepatuhan } & \multirow{3}{*}{ Total } & \multirow{3}{*}{$\underset{\%}{\text { Jumlah }}$} & \multirow{3}{*}{$p$} \\
\hline & \multicolumn{2}{|c|}{ Tidak patuh } & \multicolumn{2}{|c|}{ Patuh } & & & \\
\hline & $f$ & $\%$ & $f$ & $\%$ & & & \\
\hline Kurang & 12 & 20 & 0 & 0 & 12 & 20 & \\
\hline Cukup & 12 & 20 & 6 & 10 & 18 & 30 & 0,000 \\
\hline Baik & 0 & 0 & 30 & 50 & 30 & 50 & \\
\hline Total & 24 & 40 & 36 & 60 & 60 & $100 \%$ & \\
\hline
\end{tabular}

Berdasarkan tabel 4.7 didapatkan hasil bahwa responden dengan pengetahuan kurang yaitu 12 orang (20\%) memiliki tingkat kepatuhan pengobatan dengan kriteria tidak patuh yaitu sebanyak 12 orang (20\%), responden dengan pengetahuan cukup yaitu 18 orang $(30 \%)$ memiliki tingkat kepatuhan

b. Analisa hubungan dukungan keluarga dengan kepatuhan pengobatan pengobatan dengan kriteria tidak patuh yaitu sebanyak 12 orang (20\%) dan patuh sebanyak 6 orang $(10 \%)$, responden dengan pengetahuan baik yaitu sebanyak 30 orang (50\%) memiliki kepatuhan pengobatan kriteria patuh sebanyak 30 orang (50\%).

Tabel 4.8

Hubungan Dukungan Keluarga Dengan Kepatuhan Pengobatan Melitus Di Wilayah Kerja Puskesmas Daik

Pasien Diabetes Tahun 2020

\begin{tabular}{|c|c|c|c|c|c|c|c|}
\hline \multirow{3}{*}{$\begin{array}{c}\text { Dukungan } \\
\text { keluarga }\end{array}$} & \multicolumn{4}{|c|}{ Kepatuhan } & \multirow{3}{*}{ Total } & \multirow{3}{*}{$\underset{\%}{\text { Jumlah }}$} & \multirow{3}{*}{$p$} \\
\hline & \multicolumn{2}{|c|}{ Tidak patuh } & \multicolumn{2}{|c|}{ Patuh } & & & \\
\hline & f & $\%$ & $\mathrm{f}$ & $\%$ & & & \\
\hline Kurang & 13 & 21,7 & 0 & 0 & 13 & 21,7 & 0000 \\
\hline Cukup & 11 & 18,3 & 9 & 15 & 20 & 33,3 & 0,000 \\
\hline
\end{tabular}




\begin{tabular}{ccccccc}
\hline Baik & 0 & 0 & 27 & 45 & 27 & 45 \\
Total & 24 & 40 & 36 & 60 & 60 & $100 \%$ \\
\hline
\end{tabular}

Berdasarkan tabel 4.8 didapatkan hasil kepatuhan pengobatan dengan kriteria tidak bahwa responden dengan dukungan keluarga kurang yaitu 13 orang $(21,7 \%)$ memiliki tingkat kepatuhan pengobatan dengan kriteria tidak patuh yaitu sebanyak 13 orang $(21,7 \%)$, responden dengan dukungan keluarga cukup yaitu 20 orang $(33,3 \%)$ memiliki tingkat c. Analisa hubungan sarana prasarana dengan kepatuhan pengobatan patuh yaitu sebanyak 11 orang $(18,3 \%)$ dan patuh sebanyak 9 orang (15\%), responden dengan dukungan keluarga baik yaitu sebanyak 27 orang $(45 \%)$ memiliki kepatuhan pengobatan kriteria patuh sebanyak 27 orang (45\%).

Tabel 4.9

Hubungan Sarana Prasarana Dengan Kepatuhan Pengobatan Pasien Diabetes Melitus Di Wilayah Kerja Puskesmas Daik Tahun 2020

\begin{tabular}{|c|c|c|c|c|c|c|c|}
\hline \multirow{3}{*}{$\begin{array}{l}\text { Sarana } \\
\text { prasarana }\end{array}$} & \multicolumn{4}{|c|}{ Kepatuhan } & \multirow{3}{*}{ Total } & \multirow{3}{*}{$\begin{array}{c}\text { Jumlah } \\
\%\end{array}$} & \multirow{3}{*}{$p$} \\
\hline & \multicolumn{2}{|c|}{ Tidak patuh } & \multicolumn{2}{|c|}{ Patuh } & & & \\
\hline & $\mathrm{f}$ & $\%$ & $\mathrm{f}$ & $\%$ & & & \\
\hline Kurang baik & 15 & 25 & 0 & 0 & 15 & 25 & 0,000 \\
\hline Baik & 9 & 15 & 36 & 60 & 45 & 75 & \\
\hline Total & 24 & 40 & 36 & 60 & 60 & $100 \%$ & \\
\hline
\end{tabular}

Berdasarkan tabel 4.9 didapatkan hasil bahwa responden dengan sarana prasarana kurang baik yaitu 15 orang (25\%) memiliki tingkat kepatuhan pengobatan dengan kriteria tidak patuh yaitu sebanyak 15 orang $(25 \%)$, d. Analisa hubungan peran petugas kesehatan dengan kepatuhan pengobatan responden dengan sarana prasarana baik yaitu 45 orang $(75 \%)$ memiliki tingkat kepatuhan pengobatan dengan kriteria tidak patuh yaitu sebanyak 9 orang $(15 \%)$ dan patuh sebanyak 36 orang $(60 \%)$.

Tabel 4.10

Hubungan Peran Petugas Kesehatan Dengan Kepatuhan Pengobatan Pasien Diabetes Melitus Di Wilayah Kerja Puskesmas Daik Tahun 2020

\begin{tabular}{|c|c|c|c|c|c|c|c|}
\hline \multirow{3}{*}{$\begin{array}{l}\text { Peran } \\
\text { petugas } \\
\text { kesehatan }\end{array}$} & \multicolumn{4}{|c|}{ Kepatuhan } & \multirow{3}{*}{ Total } & \multirow{3}{*}{$\begin{array}{c}\text { Jumlah } \\
\%\end{array}$} & \multirow{3}{*}{$p$} \\
\hline & \multicolumn{2}{|c|}{ Tidak patuh } & \multicolumn{2}{|c|}{ Patuh } & & & \\
\hline & $\mathrm{f}$ & $\%$ & f & $\%$ & & & \\
\hline Kurang baik & 15 & 25 & 0 & 0 & 15 & 25 & 0,000 \\
\hline Baik & 9 & 15 & 36 & 60 & 45 & 75 & \\
\hline Total & 24 & 40 & 36 & 60 & 60 & $100 \%$ & \\
\hline
\end{tabular}

Berdasarkan tabel 4.10 didapatkan hasil orang (25\%), responden dengan peran petugas bahwa responden dengan peran petugas kesehatan kurang baik yaitu 15 orang $(25 \%)$ memiliki tingkat kepatuhan pengobatan dengan kriteria tidak patuh yaitu sebanyak 15 kesehatan baik yaitu 45 orang $(75 \%)$ memiliki tingkat kepatuhan pengobatan dengan kriteria tidak patuh yaitu sebanyak 9 orang (15\%) dan patuh sebanyak 36 orang (60\%).

\section{PEMBAHASAN}

1. Analisa Univariat

a. Distribusi frekwensi berdasarkan pengetahuan responden
Berdasarkan penelitian didapatkan hasil bahwa distribusi frekwensi pengetahuan responden tertinggi dengan pengetahuan baik yaitu sebanyak 30 orang $(50 \%)$. Notoatmojo 
(2003) yang mengemukakan bahwa tindakan seseorang merupakan respon internal setelah adanya pemikiran dan pengetahuan. Perilaku atau tindakan kepatuhan ini dipengaruhi oleh keturunan, lingkungan, dan pengetahuan.

Penelitian Yeni Umi Qoni'ah (2017) dalam penelitian yang berjudul Hubungan Tingkat Pengetahuan Terhadap Kepatuhan Pada Pasien Diabetes Melitustipe 2 Di Rsud Sukoharjo dengan hasil uji korelasi menunjukkan bahwa nilai $\mathrm{p}$ signifikan $=0,000$ artinya kedua variabel anatara pengetahuan dengan kepatuhan memiliki nilai yang bermakna dengan arah korelasi positif. peneliti berasumsi bahwa pengetahuan mempengaruhi kepatuhan pengobatan diabetes klien dimana sejalan dengan teori Notoatmojo (2014) semakin tinggi pengetahuan pasien tentang kepatuhan minum obat maka semakin tinggi pula tingkat kepatuhan pasien terhadap penggunaan obat.

b. Distribusi frekwensi berdasarkan dukungan keluarga

Dari penelitian didapatkan hasil bahwa hasil distribusi frekwensi dukungan keluarga tertinggi dengan dukungan keluarga baik yaitu sebanyak 27 orang $(45,0 \%)$.

Hasil penelitian tersebut dapat dijelaskan dalam teori Patt, 1977 (dalamFriedman, 2014) yang menyatakan bahwa keluarga merupakan sistem dasar dimana perilaku kesehatan seseorang dengan perawatan kesehatan sudah diatur, dilakukan serta diamankan oleh keluarga sebagai bentuk perawatan yang secara preventif. penelitian Emmina (2010) yang mengatakan bahwa keluarga memberikan dukungan yang adekuat dan terus-menerus selama klien di rawat baik dukungan informasional, instrumental, serta dukungan emosional dan harga diri.

Peneliti berasumsi bahwa dukungan keluarga sangat dibutuhkan oleh pasien Diabetes untuk meningkatkan kepatuhan klien terhadap pengobatan diabetes. Hal ini karena keluargalah yang berada paling dekat dengan klien, sehingga dengan adanya dukungan keluarga yang adekuat individu yang terkait merasakan bahwa dirinya diperhatikan dan dihargai oleh keluarganya.

c. Distribusi frekwensi berdasarkan sarana prasarana

Berdasarkan penelitian didapatkan hasil bahwa distribusi frekwensi sarana prasarana tertinggi dengan sarana prasarana baik yaitu sebanyak 45 orang $(75,0 \%)$. Akses pelayanan kesehatan merupakan tersedianya sarana kesehatan (seperti rumah sakit, klinik, puskesmas), tersedianya tenaga kesehatan, dan tersedianya obat-obatan. Penelitian Bella Oktaviani (2015) dalam judul Faktor Yang Berhubungan Dengan Kepatuhan Penderita Diabetes Mellitus Dalam Menjalani Pengobatan Di Puskesmas Pudak Payung Kota Semarang Sarana dan prasarana merupakan faktor yang terdapat hubungan dengan kepatuhan pengobatan penderita Diabetes Mellitus di Puskesmas Pudak Payung Kota Semarang $(p=0,000)$

Dari hasil penelitian peneliti berasumsi bahwa sarana dan prasarana sangat berpengaruh dalam menunjang kepatuhan terhadap pengobatan diabetes klien karena apabila sarana dan prasarana yang menunjang untuk kesehatan terpenuhi dan akses mudah maka klien tidak menemukan kesulitan terutama untuk control dan mendapatkan pengobatan.

d. Distribusi frekwensi berdasarkan peran petugas kesehatan

Dari penelitian didapatkan hasil bahwa distribusi frekwensi peran petugas kesehatan tertinggi dengan peran petugas kesehatan baik yaitu sebanyak 45 orang $(75,0 \%)$. peran petugas kesehatan (perawat) dalam pelayan kesehatan dapat berfungsi sebagai comforter atau pemberi rasa nyaman, protector, dan advocate (pelindung dan pembela), communicator, mediator, dan rehabilitator. penelitian ini didukung oleh penelitian yang dilakukan oleh Ilmah dan Nurul (2015) bahwa terdapat hubungan antara dukungan tenaga kesehatan mempengaruhi kepatuhan pengobatan $(p=0,000)$. Hal ini dikarenakan interaksi antara petugas kesehatan dan pasien akan menimbulkan pemahaman terhadap kepentingan pengobatan apabila 
dalam konsultasi yang dilakukan. Peneliti berasumsi bahwa dukungan petugas kesehatan sangat berpengaruh dalam mengotrol kepatuhan pengobatan diabetes klien. Dengan adanya monitoring dan edukasi yang tepat serta secara terus menerus secara terjadwal misalnya melalui posyandu atau puskesmas maka kepatuhan pengobatan diabetes klien dapat terkontrol dengan baik.

2. Analisa Bivariat

a. Analisa hubungan pengetahuan responden dengan kepatuhan pengobatan

Berdasarkan penelitian didapatkan hasil bahwa responden dengan pengetahuan kurang yaitu 12 orang $(20 \%)$ memiliki tingkat kepatuhan pengobatan dengan kriteria tidak patuh yaitu sebanyak 12 orang (20\%), responden dengan pengetahuan cukup yaitu 18 orang $(30 \%)$ memiliki tingkat kepatuhan pengobatan dengan kriteria tidak patuh yaitu sebanyak 12 orang $(20 \%)$ dan patuh sebanyak 6 orang $(10 \%)$, responden dengan pengetahuan baik yaitu sebanyak 30 orang $(50 \%)$ memiliki kepatuhan pengobatan kriteria patuh sebanyak 30 orang $(50 \%)$.

Berdasarkan hasil uji Chi-square diperoleh nilai $\mathrm{p}=0,000$, maka dapat disimpulkan bahwa terdapat hubungan yang signifikan antara pengetahuan dengan kepatuhan pengobatan diabetes pada klien. Dari hasil penelitian dan dikaitkan dengan pendapat para ahli peneliti berasumsi bahwa pengetahuan mempengaruhi kepatuhan pengobatan Diabetes klien dimana sejalan dengan teori Notoatmojo (2014) semakin tinggi pengetahuan pasien tentang kepatuhan minum obat maka semakin tinggi pula tingkat kepatuhan pasien terhadap penggunaan obat.

b. Analisa hubungan dukungan keluarga dengan kepatuhan pengobatan

Berdasarkan penelitian didapatkan hasil bahwa responden dengan dukungan keluarga kurang yaitu 13 orang $(21,7 \%)$ memiliki tingkat kepatuhan pengobatan dengan kriteria tidak patuh yaitu sebanyak 13 orang $(21,7 \%)$, responden dengan dukungan keluarga cukup yaitu 20 orang $(33,3 \%)$ memiliki tingkat kepatuhan pengobatan dengan kriteria tidak patuh yaitu sebanyak 11 orang $(18,3 \%)$ dan patuh sebanyak 9 orang (15\%), responden dengan dukungan keluarga baik yaitu sebanyak 27 orang $(45 \%)$ memiliki kepatuhan pengobatan kriteria patuh sebanyak 27 orang (45\%).

Berdasarkan hasil uji Chi-square diperoleh nilai $\mathrm{p}=0,000$, maka dapat disimpulkan bahwa terdapat hubungan yang signifikan antara dukungan keluarga dengan kepatuhan pengobatan klien diabetes. Peneliti berasumsi bahwa dukungan keluarga sangat dibutuhkan oleh pasien Diabetes untuk meningkatkan kepatuhan klien terhadap pengobatan diabetes. Hal ini karena keluargalah yang berada paling dekat dengan klien, sehingga dengan adanya dukungan keluarga yang adekuat individu yang terkait merasakan bahwa dirinya diperhatikan dan dihargai oleh keluarganya.

c. Analisa hubungan sarana prasarana dengan kepatuhan pengobatan

Dari penelitian didapatkan hasil bahwa responden dengan sarana prasarana kurang baik yaitu 15 orang (25\%) memiliki tingkat kepatuhan pengobatan dengan kriteria tidak patuh yaitu sebanyak 15 orang (25\%), responden dengan sarana prasarana baik yaitu 45 orang $(75 \%)$ memiliki tingkat kepatuhan pengobatan dengan kriteria tidak patuh yaitu sebanyak 9 orang $(15 \%)$ dan patuh sebanyak 36 orang $(60 \%)$.

Berdasarkan hasil uji Chi-square diperoleh nilai $\mathrm{p}=0,000$, maka dapat disimpulkan bahwa terdapat hubungan yang signifikan antara sarana prasarana dengan kepatuhan pengobatan diabetes klien. Dari hasil penelitian peneliti berasumsi bahwa sarana dan prasarana sangat berpengaruh dala menunjang kepatuhan terhadap pengobatan diabetes klien karena apabila sarana dan prasarana yang menunjang untuk kesehatan terpenuhi dan akses mudah maka klien tidak menemukan kesulitan terutama untuk control dan mendapatkan pengobatan.

d. Analisa hubungan peran petugas kesehatan dengan kepatuhan pengobatan

Dari penelitian didapatkan hasil bahwa responden dengan peran petugas kesehatan kurang baik yaitu 15 orang (25\%) memiliki 
tingkat kepatuhan pengobatan dengan kriteria tidak patuh yaitu sebanyak 15 orang $(25 \%)$, responden dengan peran petugas kesehatan baik yaitu 45 orang (75\%) memiliki tingkat kepatuhan pengobatan dengan kriteria tidak patuh yaitu sebanyak 9 orang (15\%) dan patuh sebanyak 36 orang $(60 \%)$.

Berdasarkan hasil uji Chi-square diperoleh nilai $\mathrm{p}=0,000$, maka dapat disimpulkan bahwa terdapat hubungan yang signifikan antara peran petugas kesehatan dengan kepatuhan pengobatan diabetes klien. Peneliti berasumsi bahwa dukungan petugas kesehatan sangat berpengaruh dalam mengotrol kepatuhan pengobatan diabetes klien. Dengan adanya monitoring dan edukasi yang tepat serta secara terus menerus secara terjadwal misalnya melalui posyandu atau puskesmas maka kepatuhan pengobatan diabetes klien dapat terkontrol dengan baik.

\section{KESIMPULAN}

1. Berdasarkan hasil uji Chi-square diperoleh nilai $\mathrm{p}=0,000$, maka dapat disimpulkan bahwa terdapat hubungan yang signifikan antara pengetahuan dengan kepatuhan pengobatan diabetes melituspada pasien.

2. Berdasarkan hasil uji Chi-square diperoleh nilai $\mathrm{p}=0,000$, maka dapat disimpulkan bahwa terdapat hubungan yang signifikan antara dukungan keluarga dengan kepatuhan pengobatan diabetes mellitus pada pasien

3. Berdasarkan hasil uji Chi-square diperoleh nilai $\mathrm{p}=0,000$, maka dapat disimpulkan bahwa terdapat hubungan yang signifikan antara sarana prasarana dengan kepatuhan pengobatan pasien diabetes

4. Berdasarkan hasil uji Chi-square diperoleh nilai $\mathrm{p}=0,000$, maka dapat disimpulkan bahwa terdapat hubungan yang signifikan antara peran petugas kesehatan dengan kepatuhan pengobatan pasien diabetes

\section{UCAPAN TERIMAKASIH}

1. Bapak Prof. Dr Fadli Oenzil, PhD. Sp.GK, Selaku Ketua Stikes Awal Bros Batam.
2. Ibu Sri Muharni, Ners,M.Kep.Selaku Kepala Ka Prodi Ners Stikes Awal Bros Batam.

3. Ibu Rachmawaty M.Noer,Ners,M.Kes, selaku dosen penguji yang telah meluangkan waktu untuk memberi masukan dan bimbingan

4. Ibu Rizki Sari Utami, Ners,M.Kep.selaku pembimbing I yang telah sabar, bersedia meluangkan waktu dan kesempatan bagi penulis untuk berkonsultasi, memberikan masukan, pengarahan selama penyelesaian Skripsi ini.

5. Ibu Ns.Siska Natalia,MSN, Falliative Care.selaku pembimbing II yang telah sabar, bersedia meluangkan waktu dan kesempatan bagi penulis untuk berkonsultasi, memberikan masukan, pengarahan selama penyelesaian Skripsi ini.

6. Teman - teman mahasiswa konversi Kabupaten Lingga Stikes Awal Bros Batam yang telah mendukung serta memberi motivasi untuk dapat menyelesaikan Skripsi ini.

\section{DAFTAR PUSTAKA}

Buckman Robert, Chris McLaughlin. 2010. Apa yang Seharusnya Anda Ketahui Tentang Hidup Dengan Diabetes. Yogyakarta: Marshall

Fitriyani. 2012. Faktor Resiko DM Tipe II Di Puskesmas Kecamatan Citangkil DanPuskesmas Kecamatan Pulo Merak Kota Cilegon. [Skripsi]. Jakarta :Fakultas Kesehatan Masyarakat Universitas Indonesia.

Gahayu, S. A. 2014. Buku Ajar Metode Penelitian kesehatan (edisi 2). STIKes Hang Tuah.

Hakim lukman. 2018. Faktor-faktor yang berhubungan dengan kepatuhan pengobatan pasien hipertensi di wilayah kerja puskesmas pancur. Batam: Universitas Awal Bros.

Hannan, Mujib. 2013. Analisis Faktor Yang Mempengaruhi Kepatuhan Minum Obat Pada Pasien Diabetes Melitus Di 
Puskesmas Bluto Sumenep.Wiraraja Medika. Vol.3. No.2.

Irianto K. 2014. Epidemiologi Penyakit Menular dan Tidak Menular : Panduan Klinis. Bandung : Alfabeta.

Juliansyah T, Veny E dan Bayhakki. 2014. Hubungan Dukungan Keluarga Dengan Mekanisme Koping Pasien Diabetes Mellitus. Jurnal Ilmu Keperawatan. Universitas Riau. Jom PSIK. Volume. 1(2). Tahun 2014.

Kementrian Kesehatan Republik Indonesia. 2013. Profil Kesehatan Republik Indonesia Tahun 2013. Jakarta : Kementrian Kesehatan Republik Indonesia.

Kementrian kesehatan RI. 2014. Situasi dan Analisis Diabetes. Jakarta selatan: kementrian kesehatan RI.

Kementrian kesehatan. 2013. Pedoman Pengendalian Diabetes Melitus Gastasional. Jakarta

Kementrian kesehatan. 2013. Pedoman teknisi penyelenggaraan pengendalian penyakit tidak menular di puskesmas. Jakarta: Kementrian Kesehatan RI.2012

Kementrian Kesehatan RI. 2019. .Hari Diabetes Sedunia Tahun 2018,Pusat Data dan Informasi ,Jakarta Selatan

Kristianingrum Y dan Kondang B. 2011. Dukungan Keluarga Dan Kepatuhan Minum Obat Pada Orang Dengan Diabetes Mellitus. Psycho Idea.Volume 9(2). Tahun 2011. ISSN 1693-1076

Niven. 2012. Psikologi Kesehatan : Pengantar Untuk Perawat dan Profesional. Jakarta : EGC.

Notoatmodjo Soekidjo 2014. Ilmu Perilaku Kesehatan. Jakarta: Rineka Cipta.

Notoatmodjo Soekidjo .2018. Metodologi penelitian kesehatan. Jakarta: Rineka Cipta.

Piemonte Lorenzo 2019. Rumah Diabetes Tipe 2. (Online) https://udf.org/52-aboutdiabetes.html. Diakses 16 Januari 2020 pk 11.34 WIB

Puspita Juniyanti. 2012 perilaku penderita diabetes melitus rawat jalan di rumah sakit umum daerah rantaprapat kabupaten labuhanbatu dalam pengaturan pola makan tahun 2011. Medan. Universitas Sumatera Utara Puskesmas Daik. 2018. Profil puskesmas daik lingga tahun 2018.

Riskesdas. 2018. Laporan Nasional Riskesdas 2018. Lembaga Penerbit Badan Penelitian dan Pengembangan Kesehatan. Jakarta

Schteingart David E. 2014. Patofisiologi: konsep klinis proses-proses penyakit e/6. vol 2. Jakarta: EGC

Shofiyah Siti dan Henni Kusuma (2014). Hubungan Antara Pengetahuan Dan Dukungan Keluarga Terhadap Kepatuhan Penderita Diabetes Mellitus (DM) Dalam Penatalaksanaan Di Wilayah Kerja Puskesmas Srondol Kecamatan Banyaumanik Semarang. (Online), Program studi ilmu keperawatan FK universitas diponegoro.https://jurnal.unimus.ac.id Diakses 31 Desember 2019 pk 13.47

STIKes Awal Bros Batam. 2019. Panduan Skripsi. Batam: Program Studi Ilmu Keperawatan STIKes Awal Bros Batam.

Sugiyono. 2012. Statistk Untuk Penelitian. Bandung : Alfabeta

Tandra Hans. 2019. Diabetes Masih Bisa Dikalahkan. Yogyakarta: Rapha Publishing.

Tombokan Vera. dkk .2015. Faktor-Faktor Yang Berhubungan Dengan Kepatuhan Berobat Pasien Diabetes Mellitus Pada Praktek Dokter Keluarga Di Kota Tomohon. (online), Fakultas kesehatan masyarakat universitas sam ratulangi manado. Program pascasarjana universitas ratulangi manado, https://ejournal.unsrat.ac.id/. Dikases 31 desember 2019 pk 13.26 WIB

World Health Organization. 2015. Fact Sheets Of Diabetes Media Center. Diakses tanggal $30 \quad$ November 2015. http://www.who.int/mediacenter/factsheets /fs312/en/

Yulia siti. 2015. faktor-faktor yang mempengaruhi kepatuhan dalam menjalankan diet pada penderita diabetes militus tipe. Semarang: Universitas Negeri Semarang. 